\title{
当教室における中耳炎手術の遠隔成績
}

1968年から1978年までの11年間に行なわれた手術症例について—

\author{
鵜飼幸太郎・三吉 康郎・坂倉 康夫 \\ 山際 幹和・間島 雄一・由井誠一郎
}

\section{A Long-term Follow-up Study of Middle Ear Surgery}

Conducted in the 11 years from 1968 to 1978

\author{
Kotaro Ukai, Yasuro Miyoshi, Yasuo Sakakura, Mikikazu Yamagiwa, \\ Yuichi Majima and Seiichiro Yoshii \\ (Mie University)
}

The purpose of this study was to analyze the results of the long-term follow up of the 325 ears operated upon during the 11 years from 1968 to 1978 . According to the 166 patients who answered our questionnaire, ear discharge was complained of in 45 percent of the cases and hearing deterioration in 65 percent thereof.

In a total of 115 ears, on which we were able to carry out otoscopic examination and pure-tone audiometry, 49 percent underwent surgery for cholesteatoma; 42 percent, for chronic supperative otitis media; 4 percent, for tuberculosis of the middle ear; and 5 percent received surgery a second time on the middle ear. Of those, 46 ears underwent intact canal wall tympanoplasty; 32 ears, classical tympanoplasty; 19 ears, modified radical mastoidectomy; and 18 ears, radical mastoidectomy.

Recurrence of perforation of the reconstructed ear drum was found in 44.7 percent and recurrence of ear discharge was present in 43 percent of the total; in 61 percent of the ears that had received radical mastoidectomy, in 47 percent of those with modified radical mastoidectomy in 56 percent of those with classical tympanoplasty and in 24 percent of those with intact canal wall tympanoplasty. Long-term hearing results were unsatisfactory; only 18.4 percent of the patients experienced improvement in postoperative hearing but postoperative hearing was depressed in 40 percent of the cases.

\section{は じめに}

耳鼻科領域における慢性中耳炎と慢性副鼻腔炎は耳及び鼻における代表的疾患の 1 つであるが， 手術術式の進歩において両者の間に著るしい差を惑じさせる．即ち慢性副鼻腔炎に対する上顎洞穊 骨洞根本手術は，和辻一 Denker 式にしろ Caldwell-Luc 式にしろ半世紀以上経過した今日なお 1 部の施設を除き各病院において実用化されている手術法である。一方中耳炎の手術においては, 
1956年 Wullstein ${ }^{1)}$ が鼓室成形術を発表してから今日まで種々の改良がかえられ現在に至ってお り，鼻に比べ著るしく進歩していると考えられている.

我々の教室における中耳炎手術は1962年以来主にWullstein の発表した鼓室成形術を行って来 たが1978年 8 月より乳様突起を削開せずに外耳道を拡大する新しい手術法22を取り入れかなり良い 成績をあげている ${ }^{3)}$. 今回はこれら新しい手術法を採用する前の1968年 1 月から1978年 8 月までの 11年 8 ケ月の間に行われた手術成績について検討した.

\section{研 究 方 法}

1968年 1 月から1978年 8 月までの 11 年 8 ケ月 間に三重大学耳鼻咽喉科学教室において行われ た慢性中耳炎症例 325 名を対象としてアンケー ト調査を行い回答して来た者について大学病院

\section{成}

1. アンケート調查成績：325名を対象とし てアンケート調査を行ったところ回答して来た もの 166名, 配達不能で戻って来たもの 69 名, 未回答 90 名で回収率は $64.8 \%$ であった. 166名 のアンケート調査の結果は次の如くである.

（1）手術を受けて（159通）

$\begin{array}{clr}\text { 非常によかった } & 43 \text { 通 } & 27.0 \% \\ \text { よかった } & 73 & 45.9 \% \\ \text { どちらでるない } & 31 & 19.5 \% \\ \text { 入院しなければよかった } & 12 & 7.5 \%\end{array}$

（2）退院時の耳の状態は入院前に比べ（163 通 回答)

$\begin{array}{lll}\text { たいへんよくなった } & 22 \text { 通 } & 13.5 \% \\ \text { よくなった } & 82 & 50.3 \% \\ \text { 変らない } & 36 & 22.1 \% \\ \text { 悪くなった } & 23 & 14.1 \%\end{array}$

（3）退院してから現在まで（162通）

症状はないが時々診察を受けている

44 通 $27.2 \%$

症状があるが医者に通わず 19

$11.7 \%$

症状がないので全く医者に通わず

24

$14.8 \%$

症状があるので時々通院

69

$42.6 \%$

症状があるので毎日通院

6

$3.7 \%$

(4) 現在の手術側の耳の状態について a. 耳漏（153通回答）全く出ない
耳鼻科受診を依頼, 聴力検査, 自覚症状, 局所 所見, 耳管通気度等について調査し初診時の検 査成績あるいは手術術式等と比較検討した。

績

$\begin{array}{lll} & 84 \text { 通 } & 54.9 \% \\ \text { 時々出る } & 46 & 30.1 \% \\ \text { 毎日出る } & 23 & 15.0 \%\end{array}$

b。耳痛（146通）全くない99通 $67.8 \%$

時々ある $45 \quad 30.8 \%$

毎日ある $21.4 \%$

c. 聴力 (159通) 大変よい 3 通 $1.9 \%$

よい $18 \quad 11.8 \%$

変らない $35 \quad 22.0 \%$

悪い $50 \quad 31.4 \%$

ほとんど聴えない $53 \quad 33.3 \%$

d。めまい（142通）全くない90通 63.4\%

時々ある $52 \quad 36.6 \%$

毎日ある $000 \%$

e. 味覚 (144通) 正常 130通 90.3\%

少し悪い $85 \%$

悪い $503 \%$

全く味が分らない $110.7 \%$

f. 耳鳴 (156通) 全くない 51通 $32.7 \%$

時々ある $60 \quad 38.5 \%$

毎日ある $40 \quad 25.6 \%$

寝れない程やかましい $53.2 \%$

2. 検査成績：アンケートに回答のあった 166名に大学病院耳鼻科受診を依頼し局所の診 察及び聴力検査を施行出来たのは $115 耳$ 耳であっ た。 
（1）手術時の年令及び性別分布(表 1)：10才 から50才までが 88 例と全体の約 $80 \%$ を占めてお り，9才以下は11例，50才以上 12 例であった. 最年少症例は真珠腫性中耳炎の 3 才，最年長症

表 1 症例の年齢と性別分布（111例）

\begin{tabular}{l|r|r}
\hline \hline & 男 $\quad$ 性 & 女 \\
\hline $0 \sim 9 才$ & $9(8)$ & $2(2)$ \\
$10 \sim 19$ & $11(4)$ & $10(5)$ \\
$20 \sim 29$ & $18(6)$ & $9(3)$ \\
$30 \sim 39$ & $13(7)$ & $8(4)$ \\
$40 \sim 49$ & $8(6)$ & $11(4)$ \\
$50 \sim 59$ & $7(2)$ & $3(1)$ \\
$60 \sim$ & & $2(1)$ \\
\hline
\end{tabular}

（）は真珠腫症例

表 2 中耳炎手術の適応となった中耳疾病（115耳）

\begin{tabular}{|c|c|c|c|c|c|}
\hline & $\begin{array}{l}\text { 男 } \\
\text { 右 }\end{array}$ & $\begin{array}{c}\text { 性 } \\
\text { 左 }\end{array}$ & $\begin{array}{l}\text { 女 } \\
\text { 右 }\end{array}$ & $\begin{array}{c}\text { 性 } \\
\text { 左 }\end{array}$ & \\
\hline 慢性化膿性中耳炎 & 15 & 11 & 9 & 13 & $48(41.8 \%)$ \\
\hline 真珠腫性中耳炎 & 15 & 21 & 12 & 8 & $56(48.7 \%)$ \\
\hline 結核性中耳炎 & 2 & 0 & 1 & 2 & $5(4.3 \%)$ \\
\hline \multirow[t]{2}{*}{ 再 手 術 } & 3 & 1 & 1 & 1 & $6(5.2 \%)$ \\
\hline & 35 & 33 & 23 & 24 & 115 \\
\hline
\end{tabular}

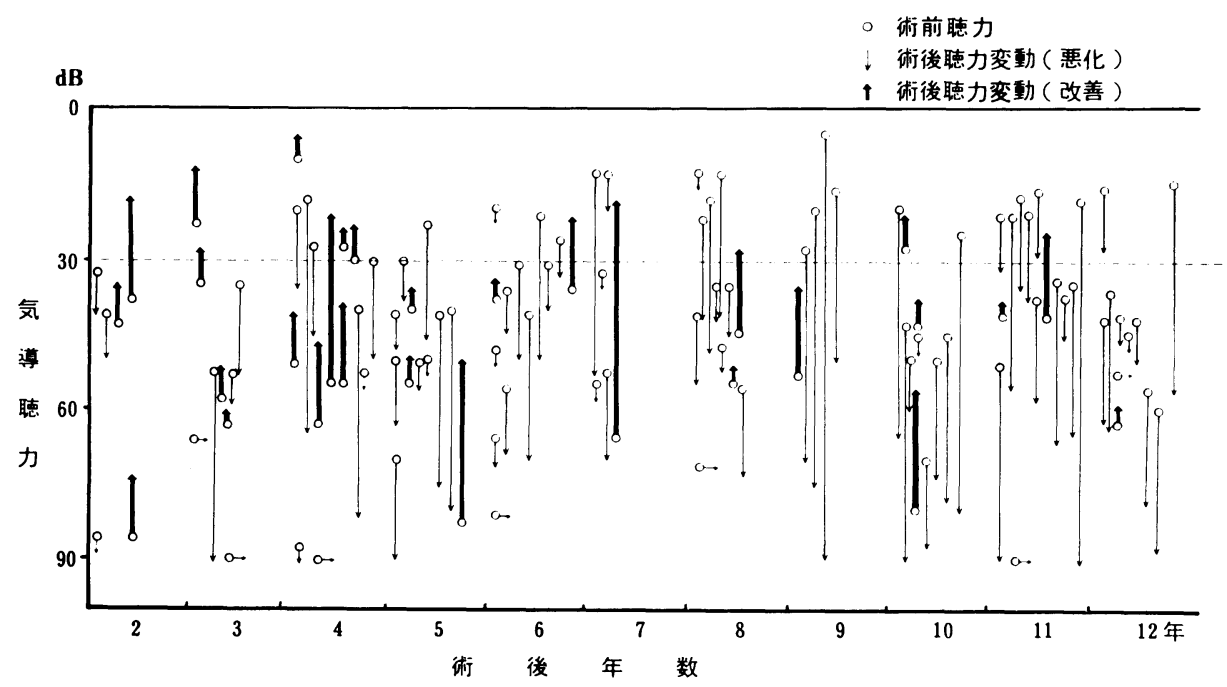

図 1 術後聴力変動（会話音域の純音気導聴力損失の算術平均 3 分法にて表現）
例は結核性中耳炎の75才であった. 真珠腫の占 める割合は 9 才以下において最も高く 11 例中 10 例 $91 \%$ であった. 男女比は 3 対 2 でやや男性に 多い傾向にあった。

（2）中耳炎手術の適応となった中耳疾患（表 2 ）：真珠腫性中耳炎が最も多く $48.7 \%$, 次い で慢性化膿性中耳炎 $41.8 \%$ であった.

（3）中耳炎手術術式(表 3)：最も多く用いら れた術式は外耳道後壁保存鼓室成形術で全体の 40\%, 次いで外耳道後壁を保存しない鼓室成形

表 3 中耳炎手術術式

\begin{tabular}{lcc}
\hline \hline $\begin{array}{l}\text { 中耳根治手術 } \\
\text { 保存的根治手術 } \\
\text { 鼓室成形術 }\end{array}$ & $18(10)$ & $15.7 \%$ \\
& $19(14)$ & $16.5 \%$ \\
外耳道後壁保存せず & $32(22)$ & $27.8 \%$ \\
外耳道後壁保存 & $46(10)$ & $40.0 \%$ \\
\hline
\end{tabular}

表 4 鼓室成形術の術型（78耳）

\begin{tabular}{rrr}
\hline \hline W- I 型 & $32(7)$ & $41.0 \%$ \\
W- II 型 & $12(6)$ & $15.4 \%$ \\
W-III 型 & $27(14)$ & $34.6 \%$ \\
W- N 型 & $7(5)$ & $9.0 \%$ \\
\hline & $78(32)$ & $100 \%$
\end{tabular}


術であった。

（4）鼓室成形術の術型(表 4)：Wullstein の 分類に従い W- I 型〜W-IV型と記載しコルメラ を使用した場合も，それぞれの基本術型に含め た. 最も多く用いられた術型はW-I 型で $41 \%$, 次いで W-III型であった。

（5）術後聴力変動(図 1)：全体としてみると 聴力低下を来した症例は79耳 $68.7 \%$, 不変例 7 耳 $6.1 \%$ ，術後聴力改善例は 29 耳 $25.2 \%$ であっ たが，術後期間が 5 年以内の症例について検討 してみると，42耳中 17 耳 $(40.5 \%)$ に聴力の改 善を認めた。しかし術前の気導聴力損失が 30 $\mathrm{dB}$ 以内の軽度難聴例 34 耳中 22 耳 $64.7 \%$ が術後 $30 \mathrm{~dB}$ 以上の難聴を来しており，術前 $30 \mathrm{~dB}$ 以 上の難聴例 81 耳中, 術後 $30 \mathrm{~dB}$ 以内の聴力に改 善した症例はわずかに 7 耳 $8.6 \%$ であった.

又術後の聴力を会話音域の純音気導聴力損失 の算術平均 3 分法にて表現し, 小西等の判定基 準4) に従い, 術後の聴力損失が $30 \mathrm{~dB}$ 以内のも のか, 又は術後の聴力損失が $30 \mathrm{~dB}$ 以内に達し ないが術後より $11 \mathrm{~dB}$ 以上改善されたものを聴 力良好群, 術前術後の聴力変化が $10 \mathrm{~dB}$ 以内で あって術後 $30 \mathrm{~dB}$ 以内の聴力に達しなかったも のを聴力不変群, 術前より $11 \mathrm{~dB}$ 以上低下した ものを聴力悪化群として分類してみると表 5 の ようになる。良好群は 21 耳 $18.4 \%$, 不変群 46 耳 $40.4 \%$ ，悪化群 47 耳 $41.2 \%$ であった。

(6) 耳内所見（表 6 ）：114耳のうち耳内所見

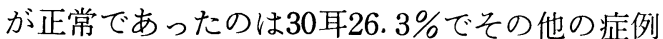
は何らかの異常所見を認めた．異常所見のらち 最も多く認めたのは鼓膜穿孔と耳漏で全体の約 $45 \%$ に認められた。 その他鼓膜陥凹，鼓膜浅在 化, 真珠腫塊, 外耳道後壁の穿孔又は陥凹を約 $10 \%$ 前後に認めた．又外耳道後壁を保存しない 手術例の 44\%近くに乳突腔のびらんを認めた.

これら耳内所見を術式別, 術後聴力の改善度 別に検討してみた。

a. 聴力良好群(表 7 )：良好群の症例数が少 いため，あまりはっきりした傾向は認められな いが，耳内゙正常であった症例はわずか 6 耳 $28.6 \%$ ，耳漏や鼓膜穿孔を認めたもの 7 耳 33.3

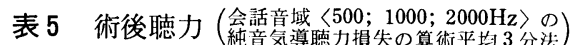

\begin{tabular}{|c|c|c|c|c|}
\hline 良 & 好 & 群 & 21耳 & $18.4 \%$ \\
\hline 不 & 変 & 群 & 46 & $40.4 \%$ \\
\hline 悪 & 化 & 群 & 47 & $41.2 \%$ \\
\hline & & & 114 & $100 \%$ \\
\hline
\end{tabular}

表 6 耳内所見（114耳）

\begin{tabular}{lcc}
\hline \hline 正 常 & 30 & $26.3 \%$ \\
鼓膜陥凹 & 16 & 14.0 \\
鼓膜浅在化 & 11 & 10.0 \\
鼓膜穿孔 & 51 & 44.7 \\
耳 漏 & 49 & 43.0 \\
真珠腫塊 & 10 & 8.8 \\
外耳道穿孔又は陷凹 & 8 & 7.0 \\
乳突腔びらん & 30 & $43.5 \%$
\end{tabular}

聴力良好群 (21耳)

表 7 術後聴力と耳内所見

\begin{tabular}{|c|c|c|c|c|c|c|c|c|c|}
\hline & \multirow{2}{*}{ 保存的根治 } & 鼓室成形 & \multicolumn{2}{|c|}{ （外耳道保存） } & \multicolumn{4}{|c|}{ 鼓室成形(外耳道保存せず) } & \multirow{2}{*}{ 計 } \\
\hline & & W- I II & III & $\mathrm{N}$ & W- I & II & III & $\mathrm{N}$ & \\
\hline 正 常 & 2 & & 1 & & 1 & & 2 & & 6 \\
\hline 鼓膜陷凹 & 3 & 1 & & & 1 & 1 & & & 6 \\
\hline 鼓膜浅在化 & & 1 & & & & & & & 1 \\
\hline 鼓膜穿孔 & 2 & & 1 & 1 & & & & 3 & 7 \\
\hline 耳 漏 & 3 & & 1 & & 1 & & & 2 & 7 \\
\hline 真珠腫塊 & & & & & & 1 & & 1 & 2 \\
\hline 外耳道穿孔又は陷凹 & & & & & & & 1 & & 1 \\
\hline 乳突腔びらん & 6 & & & & 2 & & & 1 & 9 \\
\hline
\end{tabular}


聴力不変群 (46耳)

表 8 術後聴力と耳内所見

\begin{tabular}{|c|c|c|c|c|c|c|c|c|c|c|c|}
\hline & \multirow{2}{*}{ 中耳根治 } & \multirow{2}{*}{ 保存的根治 } & \multicolumn{4}{|c|}{ 豉室成形 (外耳道保存) } & \multicolumn{4}{|c|}{ 㱠室成形(外耳道保存せず) } & \multirow{2}{*}{ 計 } \\
\hline & & & W- I & II & III & $\mathrm{N}$ & W- I & II & III & N & \\
\hline 正 常 & 2 & & 5 & & 1 & & & & 4 & 1 & 13 \\
\hline 鼓膜陥凹 & & 3 & 2 & 1 & 1 & & & & & & 7 \\
\hline 堌膜浅在化 & & & 2 & 1 & & & & & & & 3 \\
\hline 鼓膜穿孔 & 6 & 2 & 1 & & 1 & & 1 & & 8 & 3 & 22 \\
\hline 耳 漏 & 7 & 3 & 1 & 1 & 1 & & 1 & & 7 & 2 & 23 \\
\hline 真珠腫塊 & 1 & & 2 & & 1 & & & & & & 4 \\
\hline 外耳道穿孔又は陥凹 & & & 2 & & 2 & & & & & & 4 \\
\hline 乳突腔びらん & 5 & 2 & & & & & 1 & & 3 & & 11 \\
\hline
\end{tabular}

聴力悪化群 ( 47 耳)

表 9 術後聴力と耳内所見

\begin{tabular}{|c|c|c|c|c|c|c|c|c|c|c|c|}
\hline & \multirow{2}{*}{ 中耳根治 } & \multirow{2}{*}{ 保存的根治 } & \multicolumn{4}{|c|}{ 鼓室成形 (外耳道保存) } & \multicolumn{4}{|c|}{ 豉室成形(外耳道保存せず) } & \multirow{2}{*}{ 計 } \\
\hline & & & W- I & II & III & $\mathrm{N}$ & W- I & II & III & $\mathrm{N}$ & \\
\hline 正 常 & & 2 & 3 & 3 & 2 & & & 1 & & & 11 \\
\hline 豉膜陷凹 & & & 3 & & & & & & & & 3 \\
\hline 鼓膜浅在化 & & & 5 & 1 & & & 1 & & & & 7 \\
\hline 鼓膜穿孔 & 6 & 3 & 2 & 3 & 3 & & 2 & & 2 & 1 & 22 \\
\hline 耳 漏 & 4 & 3 & 2 & 2 & 3 & & 1 & & 2 & 2 & 19 \\
\hline 真珠腫塊 & & & 2 & 1 & & & 1 & & & & 4 \\
\hline 外耳道穿孔又は陥凹 & & & 2 & 1 & & & & & & & 3 \\
\hline 乳突腔びらん中 & 4 & 3 & & & & & 1 & & & 2 & 10 \\
\hline
\end{tabular}

表10 中耳炎術式と耳漏の再発率及び聴力変動

\begin{tabular}{|c|c|c|c|c|}
\hline & 症例数 & 耳漏再発 & \multicolumn{2}{|c|}{$\begin{array}{c}\text { 平均聴力損失 } \\
\text { 術 前 術 後 }\end{array}$} \\
\hline 中耳根治手術 & 18 & $11(61 \%)$ & $62 \pm 19$ & $64 \pm 17$ \\
\hline $\begin{array}{l}\text { 保存的根治手術 } \\
\text { 鼓室成形術 }\end{array}$ & 19 & $9(47 \%)$ & $31 \pm 17$ & $35 \pm 18$ \\
\hline 外耳道後壁保存せず & 32 & $18(56 \%)$ & $48 \pm 20$ & $53 \pm 20$ \\
\hline 外耳道後壁保存 & 46 & $11(24 \%)$ & $37 \pm 16^{*}$ & $56 \pm 19^{*}$ \\
\hline
\end{tabular}

* $\mathrm{P}<0.001$

\%であった. 保存的根治手術例には正常 2 耳, 鼓膜陷山 3 耳, 鼓膜穿孔 2 耳, 耳漏 3 耳, 乳突 腔びらん 6 耳と様々な所見を呈していた。

b. 聴力不変群(表 8 )：46耳の ちち 33 耳 $72 \%$ が耳内に何らかの異常所見を認め, このうちの 22 耳 $66.7 \%$ に鼓膜穿孔を認めた。これら鼓膜穿
孔例の $86 \%$ は外耳道後壁を保存しない鼓室成形 術あるいは保存的又は中耳根治手術例であっ た。な括中耳根治手術による鼓膜穿孔とは鼓室 部に移植した皮弁の穿孔を意味している。

c. 聴力悪化群(表 9 ): 耳内所見が正常であ ったのは 11 耳 $23.4 \%$ ，耳内異常所見を認めた 36 
耳中半数の 18 耳は外耳道後壁を保存した鼓室成 形術のW-I 型又はW-II型であった.

以上の結果から中耳炎術式別に耳漏の再発率 と聴力変動を検討してみると表10のようにな る. 耳漏の再発は, 中耳根治手術, 保存的根治 手術, 外耳道後壁保存しない鼓室成形術ではい ずれも50〜60\%であったが，外耳道後壁保存鼓 室成形術では $24 \%$ と低值を示した. 聴力変動に

考

我々が慢性中耳炎の手術を行ら場合, 最大の 目的は耳漏を止める事と, 聴力を改善させるこ とである.しかしこれらのいずれも著るしく不 本意な成績であった。

アンケート調査を参考に自覚的耳漏の有無と 聴力の変動を調べたところ，耳漏を訴えたもの 45. $1 \%$, 聴力の悪化 $64.7 \%$, 逆に聴力が良くな ったと答えたもの $13.2 \%$ たっった. 一方大学病 院耳鼻科にて検査を行った症例の耳内所見と聴 力検査成績を検討してみると，耳漏を認めたも の $43 \%$, 鼓膜再穿孔 $44.7 \%$, 聴力悪化 $41.2 \%$, 聴力良好 $18.4 \%$, 聴力不変 $40.4 \%$ で, 聴力悪化 については自他覚的に差があるとはいえほぼア ンヶート調査と同様の結果が得られた。

中耳炎術後の遠隔成績について現在までに各 施設から報告されている(2) 22). このらち術後 10 年以上の長期にわたり観察した報告は多くな ( ${ }^{4) ~ 10)}$. 鼓膜の再穿孔に関して本多8) は $10 \%$ (15年), 関谷等 ${ }^{5)} 27.6 \%$ (10-20年), 小林 ${ }^{9)}$ $27 \%$ (10年), 小田等 ${ }^{7)} 26 \%$ ( $8-12$ 年), 小西 等 ${ }^{4)} 24 \%$ (10年)， $\operatorname{Tos}^{10)} 9 \%$ (15年) であっ た. 又術後聴力に関しては本多息 は術前の 36 $\mathrm{dB}$ が術後 $26 \mathrm{~dB}$ に, 関谷等改善 $20.6 \%$, 悪化 $33.5 \%$, 小林改善 $19 \%$, 悪化 $18 \%$, 小西等 ${ }^{4}$ 改 善 $49 \%$, 立石等 ${ }^{6}$ 改善 $47 \%$, 小田等 ${ }^{7)}$ 改善 $14 \%$, 悪化16\%であった。術後聴力改善度の診断基準 が各施設において異っているが，我々の成績に 比べ著るしくよい。

当教室が中耳炎に対して行って来た手術術式 は表 3 に示した如く, 中耳根治手術, 保存的根
関しては, 術前術後とも最も悪いのが中耳根治 手術例で, 良いのは保存的根治術, 術後に悪化 したのは外耳道後壁保存鼓室成形術であった $(\mathrm{P}<0.001)$.

(7) 術後合併症：大学病院を受診した中耳炎 手術症例 115 耳のうち顔面神経麻痺を来した症 例は 6 耳で, このうち 3 耳は術後の 1 過性の麻 痺であった。

\section{察}

治手術，外耳道後壁を保存しない鼓室成形術， 外耳道後壁を保存した鼓室成形術の 4 種類であ る.このらち中耳根治手術は18耳で全体の15.7 \%に適用された。この術式は原則として広範囲 の真珠腫症例に適用していたとはいえ実際には 9 例 $(50 \%)$ で残りは結核性中耳炎 3 例，再于 術 3 例，慢性化膿性中耳炎 3 例であった。 そし てその成績は表10に示した如く耳漏再発11耳 $(61 \%)$, 恥力悪化 $33 \%$, 聴力不変 $67 \%$ で平均聴 力損失の変動は術前が $62 \mathrm{~dB} \pm 19$, 術後 $64 \mathrm{~dB}$ 土17であった。乳突洞と鼓室の病巣をすべて除 去して炎症を止め, 耳管を充填し粘液の排出を も停止させる中耳根治手術の目的が聴力を犠牲 にした耳漏停止のための手術であるとするなら ば，我々が得た耳漏の再発 $61 \%$ はあまりも高 率である. 鈴木 ${ }^{23)}$ も指摘する如くこの手術を行 っても完全に病巣や蜂巣の摘出がもずかしく, 耳漏の残る場合, 再発する場合が少なくなく, その昔は止むを得ずおこなわれたとしてもごく 例外を除いて今日では行らべき手術ではないと 云える。

保存的根治手術は19例（16.5\%）に用いられ た。この術式は上鼓室型真珠腫に限り適用（実 際には19例中14例，73\%）され，上鼓室及び乳 様蜂巣の根治的削開手術である。病変が上鼓 室, 乳突部に限局している場合には治りがよく 聴力も保存されるが, 逆に中鼓室や下鼓室等に 病変が隱されている場合には危険な手術であ る。術後の耳漏再発は $47 \%$, 聴力悪化 $32 \%$, 聴 力不変 $26 \%$, 聴力改善 $42 \%$ で, 平均聴力損失の 
変動は術前 $31 \mathrm{~dB} \pm 17$, 術後 $35 \mathrm{~dB} \pm 18$ であっ た. 術後の聴力に関しては中耳根治手術に比べ 著るしく良く, 術前後の聴力変動も一応満足の ゆく結果が得られた。しかし耳漏に関しては中 耳根治手術例と同様，高率に認められた。病変 が上鼓室, 乳様蜂巣に限局していても病巣や蜂 巣を完全に摘出することは困難であり，聴力保 存（改善ではない）のためにはよい方法である が耳漏停止のためには満足出来る術式とはいえ ない.

鼓室成形術は外耳道後壁保存の有無にかかわ らずすべての症例に乳様突起削開術を併用し た。この手術法は中耳腔を形成するとともに伝 音機構を再建し聴力を積極的に改善させる目的 で開発されたが，耳漏の再発に関しては，当教 室の場合外耳道後壁を保存しない場合より，後 壁保存の方が著るしく低くかった。しかし聴力 の変動に関しては外耳道後壁保存の有無にかか わらず術後の平均聴力はいずれも低下してお り，ことに後壁保存鼓室成形術では術前の 37 $\mathrm{dB}$ が術後 $56 \mathrm{~dB}$ と約 $20 \mathrm{~dB}$ も悪化していた $(\mathrm{P}<0.001, \mathrm{t}$ 検定 $)$. 聴力改善のために開発さ れた外耳道後壁保存鼓室成形術により, 術後こ
のような著るしい聴力の低下を来した原因とし て，この手術法は原理に根本的な無理があった とはいえ ${ }^{23)}$, 術者の鼓室成形術に対する技術的 な未熟さ, 手術術式及び術型の適応の誤り等が 考えられる。

聴力悪化群 47 耳のらち耳内所見が正常であっ た11耳（23.4\%）は術中, 又は術後に生じた内 耳炎による感音性難聴の可能性が考えられる. 又悪化群の耳内異常所見を認めた症例の半数は 外耳道後壁保存鼓室成形術の W-I 又は II 型で あった．聴力改善を目的とする手術では出来る だけ I 型に近い型にすることが理想であるが, 耳小骨の裏側に隠れた真珠腫を取り残す可能性 のある場合や，ドレナージを十分につけること が出来ない時には思い切ってIII型にすることが 必要であると考える。

以上の成績を反省し当教室では，1978年 8 月 より，慢性化膿性中耳炎に対しては外耳道桩大 乳様蜂巣非削開方式を, 真珠腫性中耳炎に対し ては段階手術による中耳再建術を積極的に採用 し，耳漏の停止及び聴力改善にかなり良好な成 績をあげつつある32.

\section{ま と め}

1968年 1 月から1978年 8 月までの過去11年 8 ケ月間に三重大学耳鼻咽喉科学教室において行われ た慢性中耳炎症例325名を対象としてアンケート調査を行い，回答したもののうち115耳について聴 力検査及び局所の診察を行い初診時の唡査所見や手術術式等と比較検討した.

1. アンケート調査において，耳漏の再発は $45 \%$ ，聴力悪化を訴えたもの $65 \%$ であった.

2. 中耳炎手術の適応となった中耳疾病は真珠腫性中耳炎が $48.7 \%$, 慢性化膿性中耳炎 $41.8 \%$ の 順であった。

3. 術式は外耳道後壁保存鼓室成形術が $40 \%$ と最も多く, 外耳道後壁保存しない鼓室成形術 27.8 $\%$, 保存的根治手術 $16.5 \%$, 中耳根治手術 $15.7 \%$ であった.

4. 鼓室成形術の術型はW-I 型 $41 \%$ ， III 型 $34.6 \%$ の順であった.

5. 術後の聴力変動は良好 $18.4 \%$, 不変 $40.4 \%$, 悪化 $41.2 \%$ であった.

6. 局所所見では正常 $26.3 \%$ ，耳漏再発 $43.0 \%$ ，鼓膜穿孔 $44.7 \%$ であった.

7. 手術術式別の耳漏再発率は, 中耳根治術 $61 \%$, 保存的根治術 $47 \%$, 外耳道後壁保存しない鼓 室成形術 $56 \%$ ，外耳道後壁保存鼓室成形術 $24 \%$ であった。

8. 手術術式別に打ける術前後平均聴力損失の変動は, 中耳根治術前 $62 \mathrm{~dB}$, 術後 $64 \mathrm{~dB}$, 保存 的根治術前 $31 \mathrm{~dB}$, 後 $35 \mathrm{~dB}$, 外耳道後壁保存しない鼓室成形術前 $48 \mathrm{~dB}$, 後 $53 \mathrm{~dB}$, 外耳道後壁 
保存鼓室成形術前 $37 \mathrm{~dB}$ ，後 $56 \mathrm{~dB}$ であった。

本論文の要旨は第 8 回日本臨床耳科学会（1980年10月 9 日）においてロ演した.

参 考 文 献

1) Wullstein, H: Theory and practice of tympanoplasty. Laryngoscope $66: 1076-1093$, 1956.

2）鈴木淳一：聴力改善術. 未発行, 1980.

3）鵜飼幸太郎, 他：三重大耳鼻科教室における最近 の中耳炎手術成績. 三重医学 $24: 227 \sim 232$, 1980.

4) 小西静雄, 他: 鼓室成形術の遠隔成績一岡山大学 耳鼻科教室における10年間（昭和38～47年）の手 術例の観察一. 日耳鼻 $79: 121-132,1976$.

5）関谷忠雄, 大塚基 : 鼓室形成術の長期遠隔成績 (その 2 )一来院による現状調查一臨床耳科 6 ： 150-151, 1979.

6）立石敏則, 他 : 教室11年間(1966-1976)の Tympanoplasty 術後成績. 日耳鼻 $80: 1501,1977$.

7) 小田隆造, 他: 鼓室成形術の遠隔成績（8-12年 後). Aud 14:139-144, 1971.

8）本多芳男：慢性中耳炎の病態之手術的療法一特に 真珠腫の対策について一. 第79回日耳鼻総会宿題 報告参考資料ならびに補遺, 1978 .

9）小林詢弥：鼓室成形術に関寸る臨床的研究. 耳鼻 19:196-219, 1973.

10) Tos $M:$ Stability of myringoplasty based on late results. ORL $42: 171-181,1980$.

11）伊勢郁夫, 他：鼓室成形術の遠隔成績一 7 年間の 手術例について一。耳鼻 25:159-167, 1979.

12）下山高生, 他：鼓室成形術について（5 年間の集 計). 耳鼻 $24: 791-795,1978$.

13）鵜木秀太郎, 他：当教室最近 4 年の間耳手術例に
ついて. 臨床耳科 $5: 222-223,1978$.

14）児玉章, 鈴木淳一：慢性中耳炎術後聴力変動につ いての観察. 臨床耳科 $3: 144-145,1976$.

15）鈴木知水：鼓室成形術に関する臨床的研究. 日耳 鼻 $72: 177-193,1969$.

16）佐々木寛, 他 : Meatotympanoplasty の術後経過 について. 耳喉 41:93-99, 1969.

17）佐藤智子：鼓室形成術後聴力に関する研究. 日耳 鼻 $65: 576-592,1962$.

18）瀧本勲, 他：鼓室成形術における語音聴力の変動 について. 耳鼻臨床 69:1057-1069, 1976.

19）伊達敬一, 他：鼓室成形術前後の語音聴力. 臨床 耳科 $4: 72-73,1977$.

20）湯浅涼，他：アンヶート調査による中耳手術患者 の観察. 臨床耳科 4:74-75, 1977.

21) Sheehy JL, Patterson $M E:$ Intact canal wall tympanoplasty with mastoiclectomy. A review of eight years' experience. Laryngoscope 77 : 1502-1542, 1976.

22) Cody DTR, Taylor WF : Tympanoplasty: Long-term hearing results with incus grafts. Laryngoscope $83: 852-864,1973$.

23）鈴木淳一：耳科学臨床とその将来一手術とくに聴 力改善手術について一. 耳鼻 $23: 771-775$, 1977.

$$
\left(\begin{array}{l}
\text { 別刷請求先: 鵜飼幸太郎 } \\
\text { 干514 } \\
\text { 三重大学医学部耳鼻咽喉科学教室 }
\end{array}\right)
$$

